\title{
Memaknai Ulang Corporate Social Responsibility: Upaya Mewujudkan Fair Responsibility
}

\author{
Tauchid Komara Yuda•
}

\begin{abstract}
CSR is essentially interpreted as a manifestation of the responsibility of the business world over the externalities arising from their production activities. But unfortunately this responsibility is only limited scope primary operationalization region without regard for the fact that externalities it has started from the first phase of extraction up to a radius of these products are marketed. Therefore, this paper seeks to encourage the existence of fair responsibility by understanding a CSR as companies attempt to produce eco-friendly products. With the company's commitment to implement eco-friendly production methods, then indirectly the company has been reducing their externalities, its same doing CSR.
\end{abstract}

\section{Keywords:}

CSR, fair responsibility, externality.

\begin{abstract}
Abstrak
Pada dasarnya CSR dimaknai sebagai wujud tanggung jawab dunia usaha atas eksternalitas yang timbul akibat aktivitas produksinya. Namun sayangnya tanggung jawab tersebut hanya terbatas lingkup wilayah operasionalisasi primer, tanpa memperhatikan fakta bahwa eksternalitas itu telah dimulai sejak fase ekstraksi pertama kali hingga radius dimana produk tersebut dipasarkan. Oleh karenanya, tulisan ini berupaya mendorong adanya fair responsibility dengan cara memahami CSR sebagai upaya perusahaan untuk memproduksi produk ramah lingkungan. Dengan perusahaan menerapkan komitmen eco-produce dalam menjalankan aktivitas ekonominya, secara tidak langsung sebenarnya perusahaan telah meminimalisir eksternalitasnya, yang berarti sama halnya melakukan CSR.
\end{abstract}

\section{Kata kunci:}

CSR, fair responsibility, eksternalitas.

\section{Pendahuluan}

Dunia usaha sebagai institusi yang berorientasi profit namun sekaligus sebagai penopang pembangunan dan pertumbuhan ekonomi makro, kini dalam kondisi yang dilematis. Tantangan pembangunan pada poin ketujuh Millenium Development Goals -yang telah dikonversi kepada Sustainable

\footnotetext{
- Mahasiswa S1 Departemen Pembangunan Sosial dan Kesejahteraan FISIPOL UGM.

Email: tauchid.komara.y@mail.ugm.ac.id
}

Development Goals- menuntut orientasi ganda antara pertumbuhan ekonomi dan kelestarian lingkungan hidup. Pertanyaannya apakah orientasi ganda tersebut dapat direalisasikan? Parameter kemajuan negara era global didasarkan pada capaian akumulasi kapital, dimana besaran investasi, raihan output dan profit, serta tingkat produktivitas menjadi indikator kunci keberhasilan, yang pada akhirnya pertumbuhan ekonomi suatu negara meningkat (Mubyarto dalam Damanik, 
2011: 4). Tidak cukup sampai disitu, cita-cita pertumbuhan ekonomi yang tinggi tidak akan pernah tercapai tanpa adanya iklim berbisnis yang memadai. Iklim berbisnis mensyaratkan komitmen pemerintah dalam memberi prioritas kebijakan suatu negara yang berorientasi pada sektor perekonomian, misalnya berupa pembukaan lahan industri dan penguatan infrastruktur -walaupun seringkali membawa konsekuensi terjadinya penurunan kualitas lingkungan hidup.

Meskipun demikian, kita tidak boleh menutup mata bahwa di dalam lingkungan melekat kepentingan paling subjektif manusia sebagai makhluk hidup. Setiap individu, membutuhkan lingkungan sebagai ruang kebutuhan hari ini yang tak bisa ditunda pemenuhannya dan sekaligus ruang kebutuhan masa depan yang tak dapat dipercepat (Lay, 2007: 157). Demikian juga tidak dapat ditampik bahwa lebih dari seperempat perdagangan barang dagangan di dunia melibatkan bahan baku yang langsung diturunkan dari basis sumberdaya alam yang menyangga perekonomian global (Hartati, 2007: 193-194). Permasalahan muncul ketika kegiatan ekonomi selalu berbasis pada hukum permintaan dan penawaran. Selama permintaan (demands) tidak bertendensi kepada soal kesejahteraan lingkungan, maka penawaran (supply), sampai pada cara-cara produksinya (mode of production) pun akan demikian. Padahal cara produksi yang dipilih akan menentukan eksternalitas yang dihasilkan. Eksternalitas ini akan ada sepanjang rangkaian kegiatan ekonomi, mulai dari proses ekstraksi, produksi sampai akhir konsumsi. Jika permintaan masih jauh dari kata ramah lingkungan, eksternalitas yang dihasilkan pun demikian. Situasi demikian pada gilirannya menuntut adanya trade-off (Stiglitz, 2000: 94) sebagai konsekuensi dari sebuah pilihan yang rasional. Dari logika konsekuensi itulah, tampak orientasi ganda paradigma pembangunan berkelanjutan menjadi tidak mudah untuk diterapkan.
Adanya kendala pada tataran praksis tersebut menuntut perlunya diintrodusir skema Corporate Social Responsibility (CSR) dengan harapan dapat menekan sektor privat untuk terlibat dalam problematika lingkungan dan sosial melalui komitmen perusahaan dalam menginternalisasi eksternalitasnya. CSR merupakan bentuk translasi dari pendekatan sustainable development pada institusi bisnis (Talioris, 2016: 3). Kendatipun begitu, penting digaris bawahi bahwa CSR ini hanya cukup mengkompensasi kerusakan lingkungan sebatas kisaran wilayah "hulu" saja. Sementara tanpa disadari, efek kerusakan lingkungan akibat industrialisasi dapat mencapai radius dimana produk didistribusikan dan dikonsumsi: seperti akumulasi sampah plastik dan limbah yang berujung pada kerusakan ekologi. Pada titik inilah praktik CSR masih belum dapat mewujudkan fairness dan belum mampu menjawab permasalahan lingkungan yang kompleks akibat aktivitas industri.

Berdasarkan problematika di atas, tulisan ini berupaya mewacanakan ulang mengenai CSR sebagai fair responsibility: yaitu pengoptimalisasian tanggung jawab perusahaan dalam menetralisir eksternalitasnya dari hulu ke hilir, berikut langkah-langkah yang diperlukan untuk mewujudkannya. Bahasan tersebut akan diulas dalam empat segmen. Pada bagian pertama, tulisan ini akan mengangkat CSR dan permasalahannya hingga mengantarkan pada suatu pertanyaan kritis apakah benar CSR merupakan jawaban atas kerusakan lingkungan akibat kegiatan produksi yang dilakukan oleh perusahaan? Kedua, tulisan ini akan mengupas tentang eksternalitas dan limitasi CSR. Tanpa disadari eksternalitas dimulai ketika produk pertama kali diekstrasi hingga radius dimana produk itu dipasarkan, untuk selanjutnya dikonsumsi, dan akhirnya menjadi sampah. Dengan begitu, akumulasi sampah seharusnya juga menjadi bagian dari tanggung jawab korporasi. Namun apakah model CSR yang ada saat ini 
mampu menjangkau permasalahan sampah yang terlanjur tersebar secara sporadis? Tentu jawabannya tidak. Pada sesi inilah perlu adanya suatu pembaharuan desain paradigma CSR. CSR harus dimaknai sebagai upaya perusahaan untuk memproduksi produk ramah lingkungan (eco-friendly product). Dengan komitmen seperti ini secara tidak langsung sebenarnya perusahaan telah meminimalisir eksternalitasnya mulai dari rangkaian ekstraksi sampai menjadi sampah.

Untuk mendorong komitmen korporasi menerapkan prinsip eco-friendly, baik cara produksinya maupun produk yang dihasilkan, dibutuhkan segmentasi permintaan pasar yang juga mendukung. Mengingat perilaku konsumsi memiliki muatan politik yang besar dalam menekan korporasi untuk mengubah cara produksinya. Pada bagian ketiga inilah, urgensi rekayasa pasar harus dilakukan secara simultan, yang melibatkan peranan masyarakat sipil dan pemerintah. Rekayasa pasar ini dimulai dari rekayasa permintaan (demand): upaya menginstitusionalisasi perilaku konsumsi yang mendasarkan pada preferensi green life style, yang pada gilirannya dapat menciptakan eco-demand. Tidak cukup rekayasa permintaan, rekayasa penawaran juga harus dilakukan: upaya mendorong gairah berbisnis dengan prinsip eco-friendy. Rekayasa penawaran ini dapat diinjeksi melalui serangkaian kebijakan promotif, maupun insentif bagi perusahaan yang berkomitmen menerapkan prinsip ecofriendly dalam aktivitas produksinya. Pada bagian akhir, tulisan ini menyimpulkan bahwa perubahan paradigma CSR tersebut merupakan suatu upaya mediasi paradigmatik mengenai etika bisnis, berikut membangun hubungan resiprosikal antara pelaku bisnis dan kepentingan lingkungan kemasyarakatan.

\section{Kilas Balik CSR dan Problematikanya}

Di era 1970-1980an isu tanggung jawab korporasi kurang peduli terhadap isu-isu kemasyarakatan dan lingkungan (Rudito,
Budimanta, dan Prasetijo, 2004: 82). Apa yang dipahami sebagai tanggung jawab korporat ini sangat melekat pada pandangan yang dibangun Friedman (Fleming dan Jones, 2013: 5). Ide pokok Friedman adalah penegasan tentang bagaimana seharusnya eksekutif perusahaan berkonsentrasi -sesuai dengan prinsip utamanya-pada maksimalisasi keuntungan; aktivitas diluar itu dianggap hanya akan mengganggu efisiensi dan efektivitas perusahaan. Oleh sebab itu, seorang eksekutif menggunakan keuntungan perusahaan untuk kegiatan karitatif yang bukan menjadi urusannya dianggap tidak etis (Damanik, 2011: 8). Pandangan ini menganggap hanya dengan korporasi berdiri di suatu negara sejatinya sudah cukup bagi perusahaan untuk melakukan tanggung jawab sosialnya. Karena keberadaannya dianggap akan menimbulkan side effect dalam bentuk meningkatnya pertumbuhan ekonomi, tersedianya lapangan pekerjaan dan berujung pada kesejahteraan sebuah negara.

\section{"...there is one and only one social responsibility of business-to use its resources and engage in activities designed to increase its profits so long as it stays within the rules of the game, which is to say, engages in open and free competition without deception or fraud" (Milton Friedman, the New York Times, 13 September 1970 dalam Broomhill, 2007: 6)}

Realitanya, pandangan ini semakin lama menjadi usang, seiring dengan maraknya eksploitasi sumber daya alam yang berlebihan dan berdampak global. Dampak-dampak negatif tersebut semakin terakumulasi seiring adanya tren sistem produksi massal yang diciptakan untuk alasan efektifitas dan efisiensi ekonomi, yang cenderung bersifat eksploitatif terhadap lingkungan. Selain itu penggunaan produk-produk sintesis sebagai konsekuensi dari sistem produksi massal tersebut juga turut 
memberikan kontribusi yang besar terhadap penurunan kualitas ekologi (Muthmainnah, 2007: 271-272). Hal tersebut dengan mudah merembet menjadi ancaman bagi kesehatan masyarakat, menghantarkan munculnya masalah-masalah sosial baru, dan menyeret sebagian orang menjadi pihak-pihak yang termarjinalisasi dalam seketika. Tidak hanya itu, kelangkaan sumberdaya alam akibat dari eksploitasi yang berlebihan pada gilirannya mengundang berkecamuknya konflik-konflik sosial (Santoso, 2007: 8). Klimaks dari semua ini terjadi pada kisaran pertengahan 19701980 an, ketika isu perubahan iklim dan menipisnya lapisan ozon di belahan bumi selatan menyeruak sebagai isu publik (Matten, 2004: 378).

Sepanjang tahun 1980-1990an, ekskalasi kritik terhadap korporasi meningkat. Permasalahan utama yang disoroti diantaranya persoalan lingkungan dan bencana yang disebabkan oleh aktivitas perusahaan-perusahaan global, berikut dipicu maraknya kasus eksploitasi pekerja anak di negara berkembang (Berenbeim, 1987 dalam Bartley, 2007: 301). Persoalan tersebut menyita perhatian aktivis dan komunitas, termasuk serikat buruh internasional, LSM pembangunan, organisasi hak asasi manusia dan kelompok-kelompok lingkungan yang mendesak perusahaan melakukan tanggung jawab sosial yang lebih komprehensif (Broomhill, 2007: 10). Mengingat keberadaan korporasi sangat berkaitan erat dengan lingkungan dan perubahan struktur sosial yang ada dalam masyarakat secara luas, oleh karenanya sudah semestinya perusahaan berkewajiban untuk mempertimbangkan kepentingan lingkungan dan masyarakat dalam setiap keputusan yang diambil (Rahim et.al, 2011: 121).

Kritik dan perdebatan yang berlangsung pada akhirnya dimediasi pada pertemuan di Rio de Jeneiro, Brazil pada 1992. Pertemuan tersebut berhasil merumuskan suatu paradigma baru dalam pembangunan, yaitu pembangunan berkelanjutan yang mengedepankan keseimbangan tiga pilar: ekonomi, sosial dan lingkungan hidup (Djajadiningrat, Hendriani, Famiola, 2011: iv). Delapan tahun sesudahnya, di tahun 2000 PBB membentuk UN Global Compact. Lembaga tersebut memberikan preskripsi tentang penyelarasan etika bisnis yang sejalan dengan paradigma sustainable development, melalui model Triple Bottom Line; profit, people, dan planet (Suharto, 2009: 107). Model ini memberi penegasan bahwa etika bisnis tidak hanya meliputi apa yang dilakukan perusahaan dengan keuntungan mereka, tetapi juga mempertimbangkan bagaimana keuntungan tersebut dihasilkan (Harvard Kennedy School dalam Tempo.co, 25 Februari 2016), dengan cara memperhitungkan dampak (eksternalitas) yang timbul dari kegiatan perusahaan pada masyarakat dan lingkungan (Taliouris, 2016:3), untuk kemudian dilakukan internalisasi.

Secara lebih teoritis dan sistematis, Carrol (Saidi dan Abidin dalam Suharto, 2009: 102) memberikan komponen-komponen yang idealnya dipenuhi oleh sebuah perusahaan dalam melakukan etika bisnis. Pertama, tanggung jawab ekonomis: motif utama perusahaan adalah profit. Dengan profit, perusahaan dapat terus hidup dan berkembang. Kedua, tanggung jawab legal: CSR dilakukan dalam rangka tunduk terhadap aturan hukum yang berlaku pada suatu negara. Ketiga, tanggung jawab etis: perusahaan memiliki kewajiban untuk menjalankan praktek bisnis yang fair dan tidak merugikan pihak-pihak lain. Norma-norma masyarakat menjadi rujukan bagi perilaku organisasi perusahaan. Keempat, tanggung jawab filantropis: perusahaan dituntut memberikan kontribusi yang dapat dirasakan langsung oleh masyarakat: meningkatkan kualitas hidup semua, baik kepada perusahaan, publik, maupun unsur-unsur yang melekat pada masyarakat seperti lingkungan hidup. Berdasar pada penjelasan tersebut, secara ringkas CSR dapat didefinisikan, sebagai 'bentuk komitmen' perusahaan dalam 
mengintegrasikan kepedulian sosial dan lingkungan kedalam aktivitas produksinya.

Perkembangan selanjutnya, konsep ini juga didorong sebagai kerangka untuk mengukur kinerja bisnis. Dimana kinerja yang diukur tidak lagi berkisar pada profitabilitas tetapi juga pada efisiensi organisasi dalam mengelola dengan manusia dan alam (Rahim et.al 2011: 120). Walau begitu, CSR belum memberikan solusi atas persoalan sosiolingkungan yang kompleks lantaran belum memiliki kerangka implementasi yang universal (lihat Fleming dan Jones, 2013: 4; Jamali dan Mirshak, 2007: 244) dan tidak menjamin sepenuhnya keterlibatan sektor privat untuk turut memasukan persoalan sosio-lingkungan sebagai bagian dari orientasi perusahaan-diluar profit- sebagaimana yang diharapkan (Clark dalam Sumarto, 2007: 351). Contoh empiriknya permasalahan pencemaran Sungai Citarum, di Kampung Balekambang, Kabupaten Bandung yang diakibatkan oleh maraknya pembuangan limbah industri pabrik ke aliran sungai tanpa proses instalasi pengolahan limbah terlebih dahulu. Terdata, 139 indutri tekstil dan tenun yang membuang limbahnya langsung ke aliran Citarum. Sekitar 1.500 industri yang berada di sekitar Daerah Aliran Sungai (DAS) Citarum: sektor industri manufaktur seperti tekstil, kimia, kertas, kulit, logam/elektroplating, farmasi, produk makanan dan minuman, dan lainnya menyumbang 2.800 ton limbah setiap harinya. Semuanya merupakan limbah cair kimia bahan bahaya beracun (B3), yang mengandung logam berat. Logamberat merupakan elemen yang tidak dapat terurai dan dapat terakumulasi melalui rantai makanan (bioakumulasi), dengan efek jangka panjang yang merugikan pada makhluk hidup. Padahal kita mengetahui di sekitarnya banyak masyarakat yang menggantungkan mata pencahariannya pada Sungai Citarum, seperti areal pertanian. Masalah ini menimbulkan berbagai penyakit seperti gatal-gatal dan diare (Green Peace dan WALHI 2012; Republika.co.id, 29 Juni 2012).
Disamping komitmen perusahaan, CSR juga menemui kendala seputar persoalan politis, teknis dan kepentingan. Persoalan politis yang dimaksud yaitu praktik rent seeking, yang memungkinkan sektor privat tetap mendapatkan perlindungan dari pemerintah meskipun telah melalaikan kewajibankewajibannya (Clark dalam Sumarto, 2007: 351-352). Dalam implementasinya Sumarto dalam studinya menuliskan bahwa CSR kerap membuahkan konflik kepentingan lantaran perusahaan telah memenuhi kewajiban membayar pajak dan pungutan lainnya kepada pemerintah pusat, sehingga banyak perusahaan merasa tidak perlu melakukan pengelolaan dampak eksternalitas. Pada sisi yang lain, pemerintah daerah dan masyarakat merasa berhak untuk mendapatkan kompensasi ekses munculnya eksternalitas. Keduanya mencoba untuk mendapatkan haknya dengan pendekatan sesuai dengan kepentingan masing-masing (2007: 357). Selanjutnya, persoalan teknis. Pemerintah belum memiliki rancangan induk atau masterplan CSR, sehingga peran pemerintah seringkali kontraproduktif. Padahal, pemerintah seharusnya lebih aktif memposisikan diri sebagai fasilitator agar perusahaan-perusahaan dapat menjalankan kegiatan-kegiatan CSR-nya lebih efektif. Di banyak tempat pun CSR masih menjadi apriori, hanya sebagai media promosi, dan baru direalisasikan setelah terjadi kerusakan lingkungan atau setelah terjadi konflik sosial. Kenyataan inilah yang membuat pelaksanaan CSR berpotensi mengalami permasalahan yang pelik (dilansir dari viva.co.id, 2014).

Dalam hal kepentingan, CSR ini merujuk pada dua hal: pertama, berseberangannya orientasi antara perusahaan yang berorientasi profit dan isu kesejahteraan lingkungan yang dinilai tidak berkaitan secara langsung dalam meningkatkan profit, bahkan cenderung mengurangi profit-terkecuali jika CSR ini turut dikomodifikasi sebagai bagian dari branding. Kedua, roda perekonomian bergerak lantaran 
ada hukum penawaran dan permintaan. Permintaan akan mempengaruhi penawaran; begitu juga sebaliknya, penawaran akan menyesuaikan dengan permintaan. Selama permintaan jauh dari kata ramah lingkungan dan ramah sosial, demikian pula halnya dengan penawaran. Hal ini menjadikan isu sosial maupun isu lingkungan bukan lagi menjadi kepentingan korporasi. Dalam konteks ini, CSR yang ada dapat dimaknai sebagai jaring pengaman bagi perusahaan dari protes masyarakat terdampak, dan tidak lebih dari sekedar instrumen guna memperlancar jalur distribusi untuk memenuhi permintaan konsumen. CSR belum berhasil menyelesaikan domain permasalahan eksternalitas yang sesungguhnya.

\section{Eksternalitas dan Limitasi CSR}

Eksternalitas pada dasarnya dimaknai sebagai dampak sampingan yang timbul baik dari aktivitas dan tindakan apapun yang dilakukan oleh pemerintah, masyarakat, juga swasta (Cahyono dan Yusuf, 2013: 4). Eksternalitas ini dapat berdampak positif maupun negatif; misalnya eksternalitas yang timbul dari kebijakan yang diimplementasikan pemerintah dapat berdampak positif, jika kebijakan tersebut mampu menjawab masalahmasalah publik dan terbukti meningkatkan kesejahteraan masyarakat. Sebaliknya, suatu kebijakan akan bedampak negatif, jika kebijakan yang diimplementasikan cenderung mengeksklusikan suatu kelompok tertentu dan hanya menguntungkan segelintir orang.

Dalam tulisan ini, eksternalitas yang dimaksud timbul sebagai dampak negatif dari aktivitas ekonomi (lihat Landes dalam Idowu, et.al. 2013: 1846) bagi lingkungan dan masyarakat yang tergantung pada lingkungan itu sendiri. Sebelum melangkah lebih jauh, berikut adalah sebuah analogi untuk memahami apa yang ingin hendak penulis utarakan. Ketika seseorang mengkonsumsi suatu olahan produk berkemasan plastik, selanjutnya kemasan tersebut dibuang menjadikan sampah, lalu terakumulasi bersama sampah-sampah lain baik itu berasal dari keluarga, kerabat, tetangga, dan seterusnya hingga akhirnya sampah tersebut membuahkan berbagai masalah bagi lingkungan di kemudian hari. Siapa yang bertanggung jawab terhadap sampah itu? Mungkin konsumen dalam hal ini dapat dikatakan sebagai pihak yang bertanggung jawab atas keberadaan sampah tersebut -tetapi tidak pada komponen dan komposisi yang terkandung dalam produk maupun kemasan. Asumsinya: dalam kegiatan ekonomi, konsumen dianggap sebagai muara akhir dalam mata rantai tata niaga perekonomian setelah sebelumnya didahului oleh fase transaksi. Fase transaksi menyimbolkan legalitas transfer kepemilikan (dan kewewenangan) atas suatu produk dari produsen atau distributor kepada konsumen. Dengan begitu kuasa (dan tanggung jawab) atas barang berada sepenuhnya pada otoritas konsumen.

Namun yang patut dikritisi, walaupun otoritas atas barang berada pada konsumen, apakah lantas tidak ada tanggung jawab bagi produsen atas sampah akhir konsumsi? Setiap upaya yang dilakukan produsen untuk menambah nilai guna pada barang, akan selalu menghasilkan eksternalitas bagi lingkungan sekitar wilayah produksi, namun belum pada produk itu sendiri. Produk baru akan nampak sebagai eksternalitas (dalam bentuk sampah) setelah melewati fase konsumsi. Fase konsumsi hanya akan terjadi setelah sebelumnya melewati transaksi, dan kegiatan transaksi tersebut baru dapat dilakukan ketika keberadaan barang memungkinkan bagi konsumen untuk mengaksesnya. Selama produk belum terdistribusi kepada konsumen, sesungguhnya tanggung jawab atas produk sepenuhnya mutlak ada pada pihak produsen, sebelum akhirnya produsen mendistribusikannya sejauhmana konsumen itu berada, agar barang tersebut menjadi accessable bagi konsumen. Artinya, walaupun tanggung jawab sampah 
produk itu berada di tangan konsumen, namun demikian yang menjauhkan 'bakal sampah' itu dari pabrik sesungguhnya produsen itu sendiri. Semakin jauh radius produk didistribusikan, semakin besar pula 'potensi' sebaran titiktitik kerusakan ekologi akibat sampah dari produk. Fenomena demikian menerangkan bahwa kegiatan transaksi pada dasarnya syarat muatan kepentingan korporasi untuk mengalihkan biaya-biaya eksternalitas -yang seharusnya juga menjadi tanggung jawab produsen- kepada masyarakat secara luas. Ibarat peribahasa 'lempar batu, sembunyi tangan': ketika korporasi mendapat profit dan konsumen mendapat kepuasaan secara personal, sedangkan orang-orang yang tidak terlibat dalam transaksi terkena dampak dari aktivitas yang dilakukan produsen dan konsumen.

Kendatipun begitu, sayangnya pihakpihak yang terdiskreditkan atas tercemarnya lingkungan tetaplah masyarakat konsumen, bukan korporasi. Hal ini logis, karena eksternalitas-eksternalitas yang sesungguhnya hanya nampak jelas ketika produk sudah dikonsumsi dan menjadi sampah. Sedang perusahaan terus melindungi diri dengan menyapu sampah yang timbul ketika proses ekstraksi berlangsung, melalui skema program CSR. Bahkan dengan skema CSR, tak jarang perusahaan justru semakin berada pada taraf keuntungan yang optimal, mengingat CSR dapat digunakan sebagai salah satu moda alternatif branding. Dengan perusahaan tetap pada status-quo-nya, perusahaan akan terus mendapat profit karena biaya eksternalitas yang tidak nampak terus dilimpahkan kepada konsumen secara tidak sadar, hingga seolah-olah harga produk itu terjangkau, dan konsumen dengan senang hati membelinya.

Jika diperhatikan tulisan atau gambar pada kemasan suatu produk yang pada intinya menginformasikan bahwa sampah tidak boleh dibuang langsung, atau instruksi sampah produk tersebut harus dibuang pada tempat-tempat khusus. Apa sesungguhnya makna dibalik gambar atau tulisan tersebut? Instruksi tersebut sesungguhnya mengandung makna tersirat bahwa "produk yang Anda beli akan menimbulkan masalah jika tidak dibuang pada tempat yang seharusnya. Produsen tidak bertanggungjawab atas risiko-risiko yang mungkin timbul dari produk yang sudah di tangan konsumen". Celakanya, sudah konsumen mengabaikan informasi atau label pada produk, pun perilaku konsumsi produk tidak ramah lingkungan melembaga.

Analogi yang penulis kemukakan sangat sesuai dengan realitas yang terjadi di Indonesia, dimana salah satu isu eksternalitas yang cukup pelik adalah permasalahan limbah sampah yang belum terselesaikan dengan baik. Sampah yang dihasilkan di Indonesia secara keseluruhan mencapai 175.000 ton per hari atau 0,7 kilogram per orang. Pada 2014, data statistik sampah di Indonesia mencatat bahwa Indonesia menduduki negara penghasil sampah plastik kedua terbesar di dunia setelah China. Jumlah sampah di Indonesia akan terus meningkat jika penanganan sampah belum serius. Diprediksikan, pada 2019, produksi sampah di Indonesia akan menyentuh 67,1 juta ton sampah per tahun (Geotimes.co.id, 10 Juli 2015). Ini belum ditambah eksternalitaseksternalitas lainnya seperti polusi udara, pencemaran tanah, berikut penyakit yang ditimbulkannya.

Berdasarkan pada pemahaman tersebut, maka pantas kalau kita meragukan apakah 'CSR yang kita kenal selama ini' memang solusi atas kerusakan lingkungan akibat keberadaan korporasi? Mampukah CSR mengembalikan hak-hak masyarakat atas lingkungan hidup yang telah direnggut? Ataukah CSR ini ibarat pil penenang bagi seorang pasien yang telah divonis dokter akan meninggal dalam waktu dekat? Apakah CSR itu fair? Gambar berikut ini menjelaskan limitasi keterjangkauan CSR.

CSR pada dasarnya tidak akan pernah cukup memberikan counter atas permasalahan 
Gambar 1.

Limitasi Keterjangkauan CSR dalam Menginternalisasi Eksternalitas

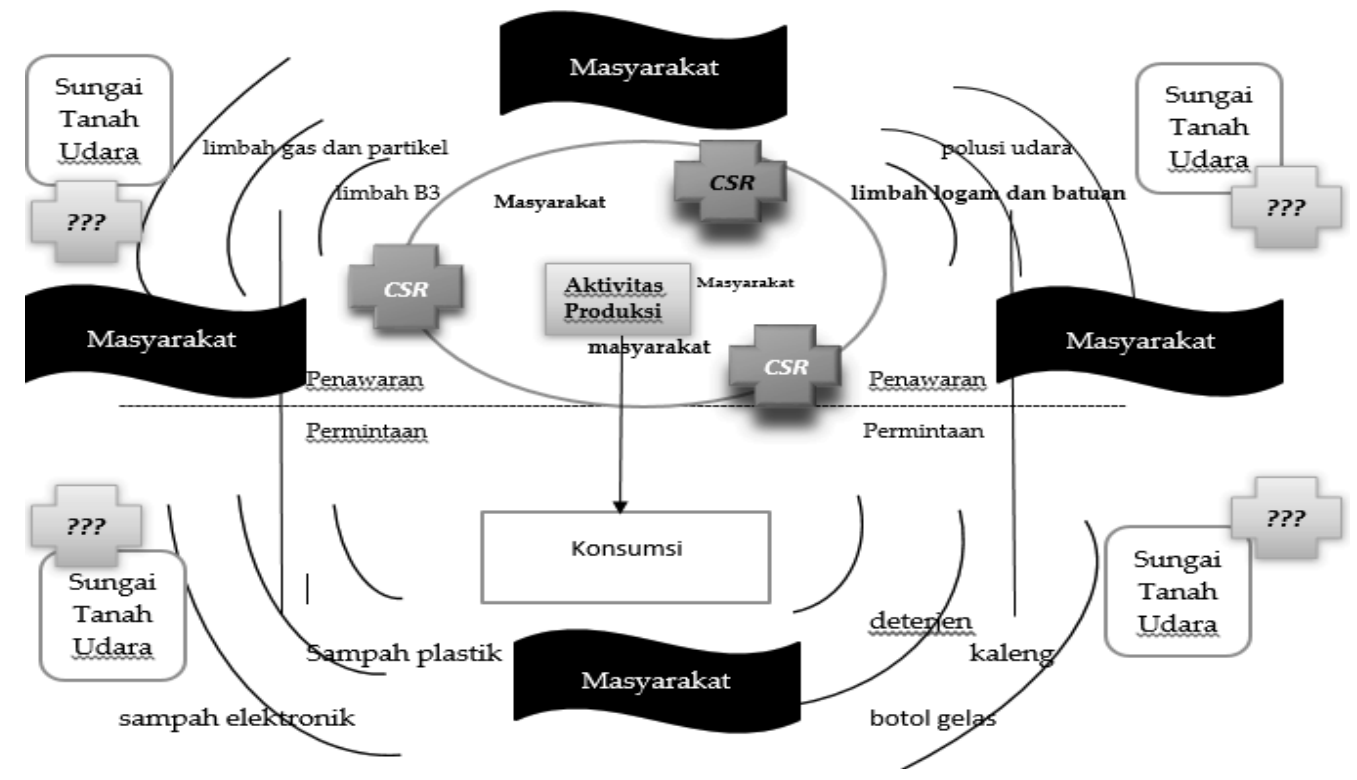

Sumber: diolah peneliti

lingkungan -dan sosial- dari hulu ke hilir. CSR yang dilakukan tidak sebanding dengan society risk yang akan dihadapi masyarakat dalam tempo 10 - 20 tahun kemudian, dan kalaupun dilakukan upaya recovery akan membutuhkan pengeluaran publik yang tidak sedikit. Atas dasar urgensi tersebut, keperluan untuk merumuskan kembali kebijakan-kebijakan CSR yang akomodatif untuk kedua unsur yang sama-sama penting dalam kebutuhan masyarakat sangatlah penting dan mendesak untuk dilakukan.

Dari sini dapat kita tarik suatu konsep CSR kepada ranah yang lebih luas. Idealnya dunia usaha juga harus bertanggung jawab atas limbah produk, sampai pada wilayah dimana produk itu dipasarkan. Namun seperti yang sudah disinggung diatas, ketika dunia usaha dituntut untuk mereduksi limbah sekitar wilayah hulu saja masih kerap mangkir, apalagi untuk mereduksi ekses eksternalitas berdasarkan cakupan radius wilayah pemasaran? Tentu tidak rasional untuk dilakukan. Sesungguhnya itulah limitasi CSR, yang (mungkin) tidak pernah disadari.

\section{Pembaharuan Paradigma CSR}

Benarkah CSR hanya mungkin dilakukan sejauh wilayah produksi saja? Apakah CSR yang fair itu benar-benar bisa dilakukan? Pada sesi inilah kita harus mencoba keluar dari pemahaman umum tentang CSR: memberikan sebagian keuntungan perusahaan untuk kegiatan sosial dan lingkungan, berikut kompensasi atas eksternalitas yang dihasilkan oleh perusahaan. Pemahaman CSR semacam itu sangat unfair. Karena kompensasi yang diberikan tidak sebanding dengan biaya sosial maupun biaya kerusakan lingkungan yang timbul, baik di wilayah terdampak disekitar areal produksi maupun eksternalitas ditempat lain. Pemahaman semacam itu juga tidak akan menyelesaikan masalah yang menjadi kekhawatiran masyarakat jangka panjang.

Pemahaman CSR harus dikaitkan langsung dengan upaya perusahaan untuk memproduksi produk ramah lingkungan atau menempatkan eco-friendly/eco-produce ${ }^{1}$

\footnotetext{
1 Istilah eco-produce, sangat dekat dengan konsep green cleaner: mengurangi resiko baik terhadap manusia dan lingkungan, dengan minimalisasi penggunaan bahan
} 
sebagai prinsip dalam menjalankan aktivitas ekonominya. Mengingat setiap produk yang dihasilkan mulai dari proses ekstraksi, proses produksi hingga akhir setelah mengalami fase konsumsi akan menghasilkan eksternalitas. Jika mode of production berikut produk yang dihasilkan korporasi menerapkan prinsip ecoproduce, tentu saja hal ini akan mereduksi atau meminimalisir potensi akumulasi eksternalitas dengan sendirinya, dengan begitu maka tingkat kerusakan ekologi juga dapat ditekan. Bukankah ini sama halnya juga dengan CSR? Pemahaman ini diharapkan dapat menyeleraskan kecengkahan antara model ideal Sustainable Development yang diharapkan yaitu mensinergikan antara pertumbuhan ekonomi dengan kesejahteraan lingkungan, dengan realisasinya yang belum representatif dalam dunia bisnis.

\section{Rekayasa Pasar}

\section{A. Pengarustaman Eco-demand dan Peranan Masyarakat Sipil}

Bagian ini akan membahas mengenai langkah-langkah taktis dan strategis agar implementasi CSR dapat mewujudkan sinergitas antara pembangunan dan orientasi kelestarian lingkungan yang dapat berkelindan satu sama lain. Perusahaan tidak lagi parsial dalam bertanggung jawab terhadap isuisu sosial dan lingkungan yang kompleks, namun meliputi rangkaian eksternalitas sejak pertama kali ekstraksi dilakukan hingga akhir produk dikonsumsi dengan cara: memasukan kepentingan masyarakat atas lingkungan ke dalam skema penawarannya dalam bisnis.

Tentu ini membutuhkan segmen pasar yang mendukung, yakni 'pasar hijau'. Untuk

sintesis, bahan kimia, maupun bahan berbahaya lainnya sebelum dan selama proses produksi (green cleaner), dengan demikian proses produksi akan didorong bergerak kearah zero waster/pollution dan produk akan dikelola sepanjang daur hidupnya yang dimulai sejak fase ekstraksi pertama kali dilakukan sampai pada saat pembuangan (Hartati, 2007: 204). menciptakan segmen pasar hijau, harus dilakukan upaya pengarustamaan perilaku konsumsi yang mendasarkan pada preferensi green lifestyle, yang pada gilirannya dapat menciptakan eco-demand (permintaan produk ramah lingkungan) secara masif. Eco-demand memiliki nilai strategis dalam mengubah suatu penawaran. Mengingat dalam aktivitas perdagangan, kita mengetahui bahwa kegiatan pemasaran/marketing merupakan upaya untuk mempengaruhi konsumen/pembeli sesuai dengan segmen agar mereka tertarik untuk membeli produk yang ditawarkan (Suminto, 2011: 202). Terbentuknya segmen eco-demand mengharuskan produsen menambah nilai lebih penawaran produk yang semula hanya berkisar pada harga, estetika, dan kualitas, kini bertambah satu aspek lagi yaitu produk 'ramah lingkungan'.

Konversi eco-demand (permintaan ramah lingkungan) guna menekan eco-production merupakan bagian dari perwujudan green economy. Green economy menjadi topik utama diskusi pada berbagai fora, baik di tingkat nasional maupun internasional yang bertujuan mendorong manusia untuk merevolusi proses pembangunan yang dilakukan, bahkan pada hal yang lebih mendasar, yakni revolusi green lifestyle (Djajadiningrat, Hendriani, Famiola, 2011: iv - v). Di Indonesia, wacana green economy dikonseptualisaskan sebagai ecofriendly product yang telah mulai dikembangkan, salah satunya oleh Kementrian Perindustrian (Kemenperin) melalui peraturan industri hijau sebagai salah satu tujuan pembangunan industri sebagaimana tercantum dalam UU Nomor 3 Tahun 2014 tentang Perindustrian. Mengingat urgensi untuk menghasilkan produk ramah lingkungan menjadi isu yang semakin penting dan strategis guna peningkatan daya saing, konsep ini seharusnya diimplementasikan secara terintergrasi, mulai dari pengadaan dan penggunaan material input yang ramah lingkungan, dan diproduksi dengan menggunakan mesin atau teknologi 
ramah lingkungan serta penanganan limbah yang efektif (Kemenperin, tanpa tahun)2.

Harvey Hartman (Font dan Wood, 2007) menyatakan bahwa masyarakat modern yang telah didominasi oleh nilai-nilai teknologi sejak pertengahan abad-19, seringkali mengeluhkan tentang sedikitnya manfaat yang diperoleh, sehingga mendorong suatu hasrat untuk mencari sesuatu yang dianggap telah hilang, yaitu kearifan lokal (nature value). Senada dengan Hartman, Neilsen (2014), sebuah lembaga yang bergerak dalam bidang informasi dan pengukuran perusahaan global termuka, dalam rilis survey terbarunya mewartakan setidaknya 55 persen dari konsumen global di 60 negara bersedia membayar lebih untuk produk dan layanan yang disediakan oleh perusahaan dengan pertimbangan sejauh mana komitmen mereduksi dampak sosial dan lingkungan. Kecenderungan tersebut menguat di Asia-Pasifik (64 persen), Amerika Latin (63 persen), Timur Tengah/ Afrika (63 persen), Amerika Utara (42 persen) dan Eropa (40 persen). Gelombang tersebut naik hingga 10 persen sejak tahun 2012, dengan wilayah yang mengalami kenaikan terbesar yaitu Amerika Latin, sebesar 13 persen. Bahkan, di bulan Oktober 2015, kenaikan persentase responden di bawah umur 20 tahun yang bersedia membayar lebih untuk merk produk yang mengedepankan prinsip eco-products meningkat dari 55 persen menjadi 72 persen (Neilsen, 2015).

Bagaimana di Indonesia? Berdasarkan dua studi yang pernah dilakukan terkait dengan eco-consumer di Indonesia (Suharjo, Ahmady, dan Ahmady, 2013; Panjaitan dan Sutapa 2011), beserta laporan survey gabungan dari tiga lembaga konsultan bisnis; Catalyze communications, ActivDesign, dan Komunigrafi (2011): munculnya eco-demand di Indonesia dilatarbelakangi oleh keprihatinan atas

\footnotetext{
${ }^{2}$ http://www.kemenperin.go.id/artikel/8810/PasarGlobal-Produk-Ramah-Lingkungan
}

masalah kesehatan, lingkungan, dan masalah sampah yang dihadapi konsumen di kotakota besar di Indonesia. Sehingga situasi ini mendorong sebagian masyarakat memiliki preferensi eco-product sebagai pertimbangan membeli barang, dengan jenis produk dominan pada olahan makanan. Walaupun begitu, sayangnya preferensi eco-product masih tidak seberapa, yakni kurang dari 10 persen populasi masyarakat Indonesia. Masyarakat masih lebih mempertimbangkan permintaan maksimal pada tataran kualitas, harga, brand, dan rekomendasi dalam membeli suatu produk. Selain itu pun akses atas eco-product ini masih terkendala soal harga, informasi yang kurang memadai, dan ketidakpercayaan masyarakat akan eco-product atau green product yang beredar.

Sebagaimana disebutkan sebelumnya, preferensi eco-demand dalam hal pangan menduduki peringkat atas sebagai jenis produk yang diminati. Suharjo, Ahmady, dan Ahmady (2013) menemukan bahwa walaupun produk pangan sudah mulai diperhatikan, namun dalam kenyataannya, masyarakat seringkali terkendala mulai dari: akses untuk membeli produk makanan organik: dimana produk organik hanya dapat ditemukan ditempat tertentu, harga lebih mahal daripada makanan konvensional, beberapa produk tidak selalu tersedia, produk cepat kadaluarsa, sulit untuk membedakan dengan non-organik, dan terbatasnya informasi tentangS manfaat produk.

Suharjo, Ahmady dan Ahmady (2013) juga menemukan bahwa banyak orangorang yang sebelumnya tidak menyadari pentingnya makanan organik menjadi beralih mengkonsumsi makanan organik secara teratur setelah mereka mendengar informasi yang jelas mengenai jaminan manfaat yang diperoleh.

Meningkatnya eco-demand pada sebagian populasi penduduk di Indonesia juga dipicu oleh pertumbuhan kelas menengah yang terus meningkat pesatyang rata-rata pertumbuhannya 


\section{Grafik 1.}

Preferensi Nilai yang Digunakan Masyarakat Indonesia dalam Mempertimbangkan Pembelian Suatu Produk

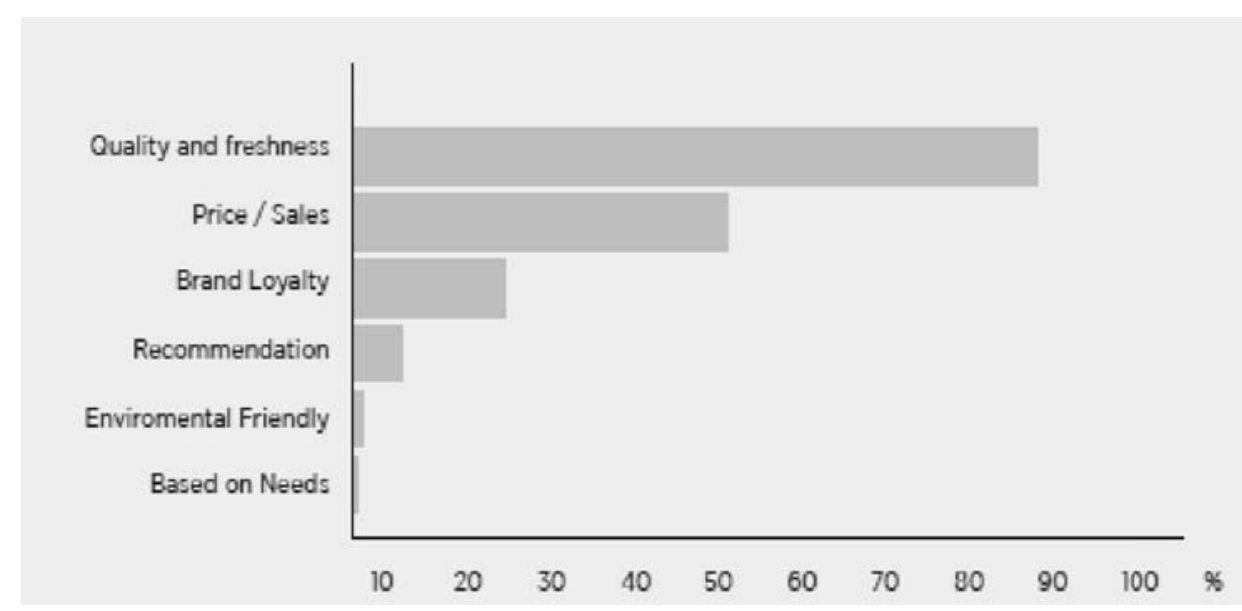

Sumber: Catalyze communications, ActivDesign, dan Komunigrafi (2011: 9)

Grafik 2.

Jenis Produk Ramah Lingkungan yang Paling Diminati Masyarakat Indonesia

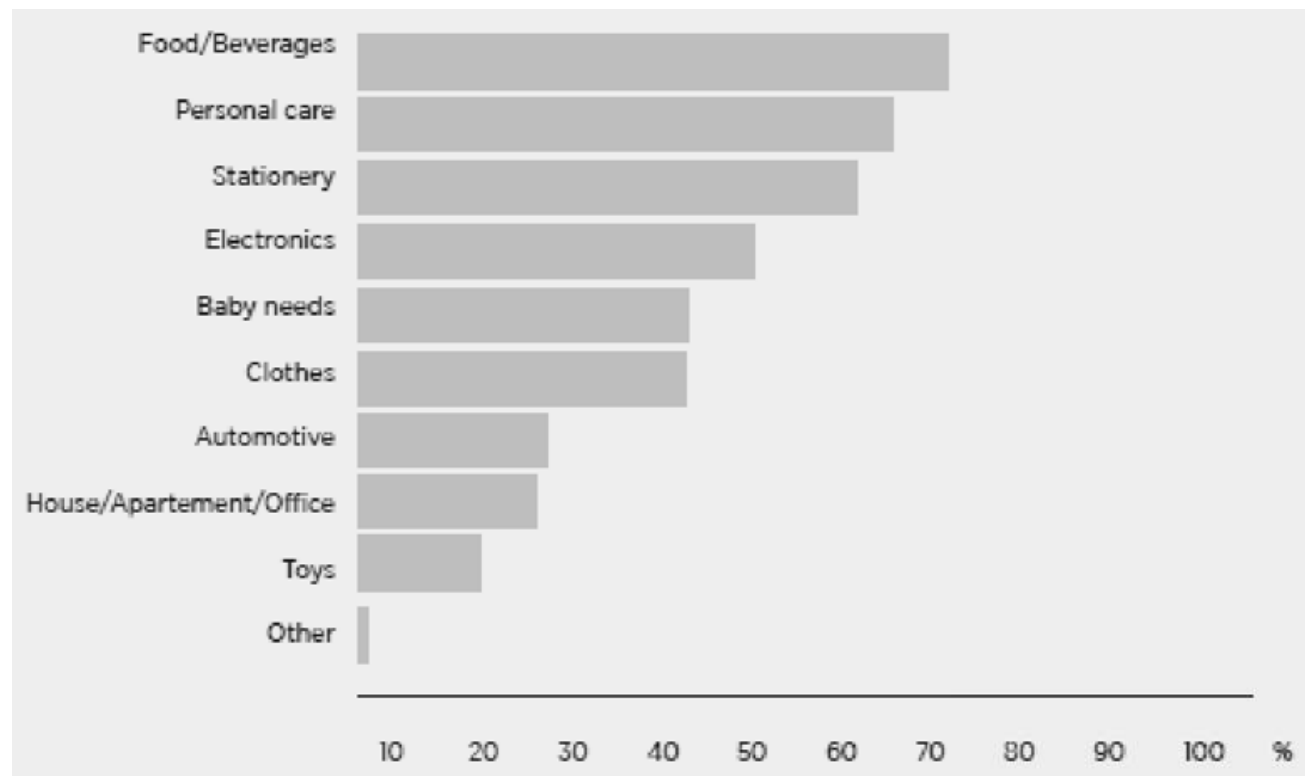

Sumber: Catalyze communications, ActivDesign, dan Komunigrafi (2011: 11)

mencapai tujuh juta orang pertahun (Kompas. com, 14 November 2015): pada 1999 hanya sekitar 25 persen dari penduduk menjadi 43 persen di tahun 2009. Disamping itu jumlah rumah tangga Indonesia dengan penghasilan sekitar US \$ 5.000 -15.000 per tahun perkirakan akan terus tumbuh dari yang sebelumnya berada di kisaran 36 persen populasi penduduk pada tahun 2010 kepada 58 persen pada tahun 2020 (Catalyze communications, ActivDesign, dan Komunigrafi, 2011). Versi lainnya, neilsen.com (2014) memprediksi 52 persen.

Poin penting yang perlu dicatat dari deskripsi yang telah dipaparkan yakni: dari 
Tabel 1.

Kendala masyarakat dalam mengakses produk pangan organik

\begin{tabular}{lc}
\hline $\begin{array}{l}\text { Masalah utama yang dihadapi konsumen dalam } \\
\text { mengkonsumsi produk organik }\end{array}$ & Presentase \\
\hline Hanya dapat diperoleh ditempat khusus & $64 \%$ \\
Harga lebih mahal & $49 \%$ \\
Bebera[a produk tidak selalu tersedia & $39 \%$ \\
Tidak ada kendala dalam mengakses & $21 \%$ \\
Produk Mudah Rusak & $14 \%$ \\
Sulit membedakan dengan produk non-organik & $12 \%$ \\
\hline
\end{tabular}

Sumber: Suharjo, Ahmady, dan Ahmady (2013). Indonesian Consumer's Attitudes towards Organic Products

40 persen lebih kelas menengah di Indonesia, ternyata preferensi eco-product tersebut hanya diminati pada kurang dari 10 persen penduduk Indonesia. Fakta serupa juga terkonfirmasi oleh temuan Panjaitan dan Sutapa (2011), dalam penelitiannya tentang green behavior, yang melibatkan mahasiswa di kota Surabaya dan terbagi atas dua grup: grup pertama, dengan rata-rata uang saku Rp500.000,00 sampai Rp2.000.000,00 dan grup kedua, antara Rp1.000.000,00 sampai Rp3.000.000,00. Dari hasil penelitian tersebut, grup kedua lebih menaruh perhatian untuk mendapatkan green product dengan harga yang lebih mahal dan bersedia untuk membayar lebih dari grup pertama. Namun secara umum, kedua kelompok secara komitmen masih rendah untuk mengikuti green lifestyle.

Dalam upaya pengarustamaan ecodemand, elemen masyarakat sipil dianggap mampu secara kapasitas mengkampanyekan adanya preferensi nilai yang merujuk pada socio-enviromental yang sudah ada dimasyarakat secara umum melalui; perilaku kolektif/ gerakan sosial (social movement); memiliki tujuan jangka panjang untuk mengubah kebiasaan masyarakat (Damsar, 2012: 130) untuk lebih mempertimbangkan eco-friendly dalam setiap pembelian produk. Pada konteks Indonesia, kontribusi komunitas anak muda akan sangat penting guna mendukung terlaksananya pengarustamaan eco-demand melalui green youth consumer movement misalnya. Mengingat pada 2015 saja, jumlah pemuda mencapai 62,4 juta orang. Itu artinya, rata-rata jumlah pemuda mencapai 25 persen dari proporsi jumlah penduduk Indonesia secara keseluruhan (BPS dalam Kompas.com, 28 Maret 2015). Dengan proporsi pemuda yang cukup besar tersebut, eco-consumer atau green consumer dapat dikampanyekan lebih intensif. Apalagi status pemuda yang masuk dalam kategori kelas menengah baru yang membuat mereka sangat dekat dengan dimensi global melalui pendekatan-pendekatan teknologi informasi. Sehingga inisiatif pemuda mencakup pembentukan berbagai diskursus (discourse) tentang green consumer akan sangat signifikan. Foucault (2012: 98)menyatakan sebuah diskursus memiliki muatan nilai yang dapat menggerakan masyarakat. Untuk dapat menggerakan masyarakat, diskursus tersebut harus memiliki modalitas penyampaian. Modalitas penyampaian yang dimaksud seperti: video propaganda, kajian, tulisan, karya seni dan sebagainya. Modalitas penyampaian berfungsi dalam membentuk konstruksi sosial atau perspektif tentang kelestarian lingkungan, pola hidup, dan konsumsi. Studi-studi poststrukturalis yang dilakukan banyak ahli seperti 
Dryzek, Nygren, Castre dan Braun, Hajer (dalam Kurniawan, 2012: 3) menunjukkan bahwa penggunaan konstruksi sosial tentang 'masalah' dan 'krisis' telah memberi pengaruh besar terhadap pilihan kebijakan lingkungan dan pembangunan. Studi-studi tersebut juga menelaah bahwa konstruksi sosial atas lingkungan telah memfasilitasi kekuatankekuatan dominan untuk mengontrol manusia dan lingkungan (Kurniawan, 2012: 3). Selain konstruksi sosial, framming penting dilakukan guna memberikan suatu identifikasi terkait dengan apa yang dianggap sebagai masalah guna proses menuju kesadaran kritis. Gregory Bateson memberikan definisi framming sebagai perangkat yang mengatur dan mengukur parameter terkait dengan "apa yang sedang terjadi". Proses framing adalah cara pelaku mengartikulasikan makna agar pesan adalah untuk menjadi dipahami (Oliver dan Johnston, tanpa tahun). ${ }^{3}$ Sebagai suatu strategi, framming bertujuan untuk memusatkan perhatian pada peranan usaha menguasai ide-ide, berikut melukiskan isu-isu lingkungan yang dibentuk dan diulang-ulang untuk menekankan suatu makna (Haryanto, Hairini, Bakar: 2013: 191).

Oleh karenaitu, guna kepentingan strategi, framming wacana yang diangkat hendaknya memperhatikan: pertama, penekanan pada makna tentang hak sosial warga negara akan kebutuhan lingkungan hidup yang merupakan komponen kesejahteraan sosial sekaligus sebagai syarat pemenuhan hidup layak. Kedua, terkait dengan konsumsi. Nilai konsumsi harus dikonstruksikan sebagai keuntungan politis bagi korporasi dalam bentuk legitimasi untuk merusak lingkungan dengan cara menghasilkan produk yang tidak ramah lingkungan karena alasan permintaan. Sehingga, jika kita mengkonsumsi produk tidak ramah lingkungan, itu sama halnya kita

\footnotetext{
What a Good Idea! Frames and Ideologies in Social Movement Research. Makalah dapat diakses di: http:// www.ssc.wisc.edu/ oliver/PROTESTS/ArticleCopies/ Frames.2.29.00.pdf (halaman 3)
}

telah berkontribusi dalam merusak lingkungan dan merenggut kesejahteraan orang lain.

Ketiga, mengangkat isu over-consumption, gaya hidup yang tidak "sustainable", pola pembangunan yang tidak sehat. Paham sadar lingkungan ini pada dasarnya berusaha mendesiminasikan wacana alam: memberikan penghargaan yang lebih atas sistem ekologi dan keragamannya beserta menghimbau sikap menahan diri dalam mengejar pertumbuhan ekonomi, demi memperoleh lingkungan yang lebih sehat (lihat: Situmeang, tanpa tahun) ${ }^{4}$.

Harapannya, pengarustamaan eco-demand pada akhirnya akan membuahkan beberapa keuntungan diantaranya: pertama, terciptanya eco-demands yang berfungsi sebagai alat proteksi non-regulasi guna membendung arus ekspansi produk impor yang mengandung bahan kimia yang merusak lingkungan yang masuk ke Indonesia -layaknya permintaan halal di Indonesia yang mendorong para pelaku usaha mau tidak mau, harus memproduksi produk dengan standar halal demi keberlangsungan produksinya. Kedua, memberi kesempatan usaha lokal ramah lingkungan untuk mendapat tempat di pasar domestik. Ketiga, dengan berkurangnya produk-produk yang tidak ramah lingkungan, hal ini dapat meminimalisir limbah yang berbahaya bagi lingkungan hidup.

\section{B. Peran Strategis Pemerintah Mendorong Green Product}

Di level pemerintahan, isu lingkungan idealnya dapat dijadikan titik rujuk politik sebagai instrumen pengaturan kepentingan bersama (Lay, 2007: 156). Karena bagaimanapun lingkungan hidup adalah barang publik yang bersifat non-rivalry dan non-exludablility (lihat: Alcock, Daly, Griggs, 2012: 135; Kotchen, 2012:

\footnotetext{
4 dalam Economic, Social, and Enviromental Policies As Drivers of Green Jobs. diakses di: www.ilo.org/wcmsp2/ groups/public/---asia/---ro-bangkok/---ilo-jakarta/ documents/presentation/wcms_164509
} 
1; Sitglizt, 2000: 128-129). Non-rivalry, merujuk pada sifatnya yang tidak terbatas, pemanfaatan lingkungan untuk kepentingan satu pihak tidak akan mengurangi kesempatan bagi pihak lain untuk turut memanfaatkannya dengan cara yang sama. Sedang non-exludablility, merujuk pada sifatnya yang penting bagi kehidupannya. Jika sampai individu yang bersangkutan kesulitan dalam mengakses barang publik tersebut, hal ini akan berakibat mengurangi kualitas hidupnya. (Kotchen, 2012: 1). Lebih jauh lagi, Tlyler Cowen melihat public good bukan hanya sebuah fakta komoditas yang harus diakses publik, public good juga berkaitan dengan kewajiban negara dalam hal pemenuhan. Negara harus bisa mengakomodasi tuntutan pemenuhan atas public good, sebagai akibat dari keterbatasan pasar dalam penyediaan dan pengelolaan efek eksternalitasnya (Ikhsanto dalam Martono, ed., 2008: 138).

Upaya pemenuhan atas lingkungan hidup ini salah satunya dapat diwujudkan dalam upaya pemerintah dalam mendorong eco-friendly dikalangan para pelaku bisnis. Cara pandang yang dibangun bukan lagi menuntut perusahaan untuk menginternalisasi eksternalitasnya setelah adanya aktivitas ekonomi, tetapi lebih kepada sebelum timbulnya eksternalitas. Hal ini dapat diwujudkan melalui modifikasi insentif eksplisit atau implisit yang ditawarkan melalui skema kebijakan lingkungan (enviromental policy) dengan tujuan: mempengaruhi harga, mempengaruhi jumlah polutan atau material yang diekstraksi dan mempengaruhi teknologi produksi (Djajadiningrat, Hendriani, Famiola, 2011: 12). Bentuk konkritnya dapat berupa pengalokasian belanja publik dalam berbagai bentuk: pertama, subsidi hibah yang ditujukan untuk mendorong dilakukannya riset pada lembaga-lembaga pendidikan yang berorientasi pada keperluan ekonomi lingkungan. Selain itu hibah dapat digunakan untuk membeli teknologi ramah lingkungan oleh sektor privat. Kedua, kebijakan promotif dalam bentuk insentif pajak: contohnya pengurangan pajak bagi produsen yang berkomitmen memproduksi produk ramah lingkungan. Ketiga, retribusi emisi5; yaitu 'pungutan' yang harus dibayar oleh suatu kegiatan industri untuk setiap unit limbah cair atau gas yang dikeluarkan ke media lingkungan. Instrumen ini ditujukan bagi pencemar untuk mengurangi ongkos yang harus ditanggung melalui pengurangan limbahnya, kebijakan ini telah digunakan di beberapa negara Eropa: Jerman, Perancis, Italia, dan Belanda (lihat Djajadiningrat, Hendriani, Famiola, 2011:12-16). Baik subsidi maupun kebijakan promotif tersebut, keduanya sangat ideal dilakukan, selain mendorong terciptanya green bussines, juga berkelindan dengan tujuan pengarustamaan eco-demand. Seperti yang telah dibahas sebelumnya, hal ini dilatarbelakangi karena preferensi konsumen tentang produk ramah lingkungan masih terbilang rendah, lantaran faktor harga yang masih sulit terjangkau. Sehingga subsidi maupun kebijakan promotif bagi perusahaan, akan berfungsi menekan biaya produksi perusahaan akan produk ramah lingkungan. Harapannya produk ramah lingkungan secara nominal dapat terjangkau oleh masyarakat.

Disamping tiga instrumentasi tersebut, idealnya pemerintah juga dapat mengupayakan kemudahan perolehan sertifikasi ramah lingkungan (eco-label) bagi produsen, khususnya bagi pelaku UMKM untuk go international. Bagaimanapun sertifikasi dianggap sebagai representasi terhadap kelayakan suatu produk, sehingga dalam mempertimbangkan produk yang akan dibeli, konsumen akan sangat memperhatikan eco-label yang saat ini menjadi prioritas segmentasi pasar internasional. Apalagi, di tengah ketatnya intensitas persaingan di aras global maupun regional ASEAN, perhatian konsumen di Indonesia

5 Retribusi emisi ini biasa dikenal sebagai pigouvian tax (lihat: Landes dalam Idowu. et. al (eds), 2013: 1847) 
tentang produk bersertifikasi masih minim. Hal tersebut memberi suatu kemudahan bagi produk luar negeri untuk menembus pasar lokal hanya bermodalkan inovasi penawaran. Sebaliknya, inovasi penawaran di Indonesia menjadi terkendala di pasar dunia, terutama bagi komunitas pembisnis skala menengah kebawah sebagai akibat dari masih tingginya biaya mendapatkan sertifikasi ecolabel itu sendiri (Yuda dalam KoranSINDO, 13 Januari 2015).

Menurut Komite Akreditasi Nasional $(\mathrm{KAN})^{6}$, skema sertifikasi ecolabel merupakan instrumen yang efektifuntukmenjaga keamanan fungsi lingkungan hidup, kepentingan sosial dan meningkatkan efisiensi serta daya saing yang memperhatikan pengelolaan dampak eskternalitas. Disamping itu, sertifikasi eco-label juga diharapkan akan memfasilitasi permintaan atas produk-produk ramah lingkungan sesuai dengan ISO 14024 dan UU Nomor 2 Tahun 1997 tentang pengelolaan lingkungan hidup, dan UU Nomor 8 Tahun 1999 tentang Perlindungan Konsumen dan Baku Mutu Lingkungan.

Di tingkat dunia, program eco-label ini dinaungi oleh sebuah organisasi yang bernama Global Ecolabelling Network (GEN). Label 'eco-friendly' berfungsi untuk menunjukkan kepada masyarakat bahwa produk yang ditawarkan adalah produk yang ramah lingkungan, dan sekaligus untuk membedakan dengan produk lain yang sejenis namun tidak ramah lingkungan (lihat Suminto, 2011:203). Selain itu, penting untuk dilakukan, yakni penyertaan informasi terkait dengan pentingnya masyarakat menempatkan indeks tanggung jawab sosial perusahaan sebagai prioritas pertimbangan dalam membeli sebuah produk. Informasi semacam itu, paling tidak dapat menjadi metode edukasi, mengapa masyarakat perlu memprioritaskan pertimbangan pembelian produk dengan preferensi ramah lingkungan.

\footnotetext{
${ }_{6}$ http://www.kan.or.id/?page_id=55\&lang=id
}

\section{Kesimpulan}

Pembangunan berkelanjutan yang menjadi titik rujuk dalam memberikan penghargaan lebih terhadap lingkungan, nyatanya hanya masih membuka celah berkedoknya korporasi untuk melakukan kerusakan lingkungan yang lebih parah. Korporasi merasa aman dengan cukup menyisihkan sedikit keuntungannya untuk membersihkan eksternalitas produksi di sekitar areal produksi, lalu diklaimnya sebagai bagian dari kapital untuk meraih simpati ratusan, ribuan, bahkan jutaan konsumen untuk membeli produk-produknya yang tidak ramah lingkungan. Semakin besar permintaan, membuat korporasi semakin percaya diri menambah jumlah produknya untuk ditukar dengan keuntungan yang berlipat-lipat. Dibalik itu semua, tanpa disadari, apa yang disebut produk-produk (baca: bakal sampah) itu hanya tinggal menunggu bom waktu hingga akhirnya meletus, yang diterjemahkan sebagai bencana global -korporasi itu kembali aman, bersembunyi dibawah teriakan: kami peduli lingkungan.

Bertumpu pada argumen di atas, perlu ditekankan kembali bahwa cara pandang yang dibangun terkait tanggung jawab dunia usaha harus diperbaharui. Bukan lagi menuntut perusahaan untuk menginternalisasi eksternalitasnya setelah adanya aktivitas ekonomi, tetapi lebih kepada sebelum timbulnya eksternalitas. Pemahaman mengenai tanggung jawab sosial perusahaan (CSR), harus dikaitkan langsung dengan upaya perusahaan untuk memproduksi produk ramah lingkungan atau menempatkan eco-friendly/eco-produce sebagai prinsip dalam menjalankan aktivitas ekonominya.

Sebagairekomendasi, pembaharuankonsep CSR ini logis diterapkan bagi formulasi kebijakan CSR di masa mendatang: dimana kebijakan CSR dengan model yang ada sekarang ini tidak perlu lagi diberlakukan bagi perusahaan yang telah menerapkan prinsip eco-produce. Rekomendasi 
ini harapannya dapat mendorong lebih banyak lagi sektor usaha yang mengedepankan prinsip eco-produceleco-friendly dalam aspek produksinya, sehingga pada akhirnya orientasi ganda antara pertumbuhan ekonomi dan kesejahteraan lingkungan dapat terealisasi.

\section{Daftar Pustaka}

Alcock, Cliff., Daly, Guy., dan Griggs, Edwin. (2012). Introducing Social Policy: Second Edition. London: Pearson Longman.

Bartley, Tim. (2007). Institutional Emergence in an Era of Globalization: The Rise of Transnational Private Regulation of Labor and Environmental Conditions. American Journal of Sociology. Vol. 113 No. 2. The University of Chicago.

Broomhill, Ray (2007). Corporate Social Responsibility: Key Issues and Debates. Dunstan Papper. Makalah dapat diakses di: http://www.dunstan.org.au/resources/ publications/Dunstan_Papers_No_1_2007. pdf

Damanik, Janianton. (2011). Menuju Pelayanan Sosial Yang Berkeadilan. Jurnal Ilmu Sosial dan Ilmu Politik. Vol. 15 No. 1, Edisi Juli.

Cahyono, Moch Farid., dan Yusuf, Hasby. (2013). Masalah Eksternalitas dan Bagi Hasil Tambang Dalam Konflik Enam Desa di Maluku Utara. Yogyakarta: Center for Security and Peace Studies UGM Makalah dapat diakses di: http://csps.ugm.ac.id/site/wp-content/ uploads/2014/12/2012-social-cohesion-innorth-maluku-4.pdf

Catalyze Communications, ActivDesign, Komunigrafik (2011). Emerging Opportunities For Green Product in Indonesia: A National Survey of Consumer Attitudes. Papper dapat diakses di: http://www. catalyzecommunications.com/research.

Damsar. (2012.) Pengantar Sosiologi Politik. Jakarta: Kencana.

Djajadiningrat, Surna Tjaja., Hendriani, Yani., dan Famiola, Melia. (2011).

Ekonomi Hijau: Green Economy. Bandung: Rekayasa Sains.
Greenpeace dan WALHI. (2012). Bahan Beracun Lepas Kendali: Sebuah Potret Pencemaran Bahan Kimia Berbahaya dan Beracun di Badan Sungai Serta Beberapa Titik Pembuangan Industri Tak Bertuan, Studi Kasus Sungai Citarum. Laporan kajian dapat diaskes di: http://www.greenpeace.org/seasia/id/ PageFiles/469211/Full\%20report $\% 20$ Bahan\%20Beracun\%20Lepas\%20Kendali. pdf

Font, Xavier dan Wood, M Epler. (2007). Sustainable Tourism Certification Marketing and Its Contribution to SME Market Access. Dalam Quality Assurance and Certification In Ecotourism, edited by Black, Rosemary dan Crabtree, Alice. CAB International, UK.

Foucault, Michael. (2012). Arkheologi Pengetahuan. IRCisod, Tanggerang.

Fleming, Peter dan Jones, Marc T. (2013). The End of Corporate Social Responsibility: Crisis and Critique. London: Sage Press.

Geotimes.co.id (2015). 2019, Produksi Sampah di Indonesia 671 Juta Ton Sampah Per Tahun. (Online). http://geotimes.co.id/2019produksi-sampah-di- indonesia-671 -jutaton-sampah-per-tahun/

Hartati, Anna Yulia. (2007). Lingkungan Hidup dan Liberalisasi Perdagangan: Upaya Mencari Jalan Tengah. Jurnal Ilmu Sosial dan Politik. Vol. 11 No. 2 Edisi November.

Matten, Dirk. (2004). The impact of the risk society thesis on environmental politics and management in a globalizing economy -principles, pro-ficiency, perspectives. Journal of Risk Research 7 (4). Edisi Juni.

Martono, Ucu (eds). Kebijakan Sosial dan Kesejahteraan. Yogyakarta: FISIPOL UGM.

Muthmainnah, Laily. (2007). Menggugah Partisipasi dan Membangun Sinergi: Upaya Bergerak dari Stagnasi Ekologis Pengelolaan Sampah. Jurnal Ilmu Sosial dan Ilmu Politik. Vol. 11 No. 2 Edisi November.

Neilsen.com. (2014). Global Consumers are Willing to Put Their Money Where Their Heart is When it Comes to Goods and Services from 
Companies Commited to Commited to Social Responsibility. (Online).

http://www.nielsen.com/us/en/presroom/2014/ global-consumers-are-willing-to-put-theirmoney-where-their-heart-is.html.

Neilsen. (2015). The Sustainability Imperative: New Insights Consumer Expectation. Global Sustainability Report.

Haryanto, Hairini Siti M, Bakar Abu. (2013). PKBI: Aktor Intermediary dan Gerakan Sosial Baru. Jurnal Ilmu Sosial dan Ilmu Politik. Vol.16 No.3 Edisi Maret.

Idowu. Samuel O et.al (eds) (2013). Enclyclopedia of Corporate Social Responsibility. Springer.

Komite Akreditasi Nasional. Ekolabel. (Online). http://www.kan.or.id/?page _id=55\&lang=id

Jamali, Dima dan Mirshak, Ramez. (2007). Corporate Social Responsibility (CSR): Theory and Practice in a Developing Country Context. Journal of Business Ethics. Vol. 72. Springer.

Konsorsium Pembaruan Agraria. (2015). Reforma Agraria dan Penyelesaian Konflik Agraria Disandera Birokrasi. Catatan Akhir Tahun 2015.

Kotchen, Matthew. (2012). Environmental and Natural Resource Economics: An Encyclopedia. dalam J.Whitehead and T. Haab (eds.). Futhercoming. Santa Barbara.

Kurniawan, Nanang Indra. (2012). Wacana Lingkungan dan Pembangunan Berkelanjutan dalam Lembaga Swadaya Masyarakat di Indonesia. Jurnal Ilmu Sosial dan Ilmu Politik. Vol. 16 No. 1 Edisi Juli.

Lay, Cornelis. (2007). Nilai Strategis Isu Lingkungan dalam Politik Indonesia. Jurnal Ilmu Sosial dan Ilmu Politik. Vol. 11, No. 2 Edisi November.

Limbong, Bernhard. (2015). Politik Air Kita. Kompas.

Oliver, Pamela E dan Johnston, Hank. What a Good Idea! Frames and Ideologies in Social Movement Research. Makalah dapat diakses di: http://www.ssc.wisc.edu/ oliver/PROTESTS/ ArticleCopies/Frames.2.29.00.pdf
Panjaitan dan Sutapa. (2011). Analysis of green product knowledge, green behavior and green consumers of Indonesian students (case study for universities in Surabaya). Papper dapat diakses di: file://C:/Users/ASUS/Downloads/ Paper\%20in\%20IEEE\%20Conference\%20 -\%20IEEM10-P-0322\%20Analysis\%20of\%20 Green \%20Product\%20Knowledge, \%20 Green\%20Behavior\%20and\%20Green\%20 Consumers\%20of\%20Ind onesian \%20 Student\%20_Case\%20study\%20for\%20 Universities\%20in\%20Surabaya.pdf

Rahim, Rahizah Abd et.al. (2011). The Importance of Corporate Social Responsibility On Consumer Behaviour In Malaysia. Asian Academy of Management Journal. Vol. 16, No. 1 Edisi Januari.

Rudito, Budimanta dan Prasetijo.(2004). Corporate Social Responsibility: Jawaban Bagi Model Pembangunan Indonesia Masa Kini. Jakarta: ICSD.

Santoso, Purwo.(2007). Environmental Governance: Filosofi Alternatif untuk berdamai dengan Lingkungan Hidup. Makalah dapat diakses di:

http:/elisa1.ugm.ac.id/files/Psantoso_ Is i pol/odufQIMY/GOOD\%20 ENIRONMENTAL\%20GOVERANCE2.doc.

Situmeang, John. Economic, Social, and Enviromental Policies as Drivers of Green Jobs. (Online). www.ilo.org/wcmsp2/groups/ public/---asia/---ro-bangkok/---ilo-jakarta/ documents/presentation/wcms_164509.

Sumarto, Mulyadi. (2007). Kepedulian Sosial Perusahaan: Cerminan Disfungsi Plurarisme Kesejahteraan. Jurnal Ilmu Sosial dan Ilmu Politik. Vol. 10, No. 3, Edisi Maret.

Suminto. (2011). Kajian Penerapan Ekolabel Produk di Indonesia. Jurnal Standarisasi. Vol. 13 No.3 Edisi Oktober.

Suharjo, Ahmady, dan Ahmady (2013). Indonesian Consumer's Attitudes towards Organic Products. Proceedings of 8th Asian Business Research Conference 1-2 April 2013, Bangkok, Thailand. 
Suharto. (2009). Pekerja Sosial Di Dunia Industri: Memperkuat CSR (Coorporate Social Responsibility). Alfabeta, Bandung.

Stiglitz, Joseph. (2000). Economics of the Public Sector. New York: WW Norton and Company.

Taliouris, Evangelos. (2016). Is CSR a policy tool for Sustainable development in South Europe? Case study in Greece. London: European Institute, London School of Economic and Political Scienes. Makalah dapat diakses di: http://www.lse.ac.uk/europeanInstitute/ research/hellenicObservatory/CMS\%20 pdf/Events/20115th\%20 PhD\%20 Symposium/Revised/TALIOURISupdated.pdf.

Yuda, Tauchid Komara. (2015). Makna Sertifikasi Bagi UMKM dalam KoranSINDO.

\section{Sumber Internet:}

Kompas.com, (2015) Menunggu Kiprah Anakanak Muda yang Jumlahnya Makin "Gemuk". (Online). http://edukasi.kompas. com/read/2015/04/28/11491251/Menunggu. Kiprah.Anak-anak.Muda.yang.Jumlahnya. Makin.Gemuk.

Kompas.com,(2015). Kelas Menengah Indonesia Minta Satu Syarat. (Online). http://bisniskeuangan.kompas.com/ read/2015/11/14/143105526/Kelas. Menengah.Indonesia.Cuma.Minta.Satu. Syarat?page $=$ all.

Neilsen.com. (2014). Meet the New Indonesian Consumer Class of 2020. (Online). http://www. nielsen.com/id/en/insights/news/2014/ meet-the-new-indonesian-consumer-classof-2020.html.

Republika.co.id. (2012). Pencemaran Limbah Industri di Citarum Makin Parah. (Online). http://www.republika.co.id/berita/nasional/ lingkungan/12/06/29/m6d2y5-pencemaranlimbah-industri-di-citarum-makin-parah.

Tempo.co. (2015). Limbah Beracun Intai Tarakan, Kementrian Siap Siaga. (Online). https://bisnis. tempo.co/read/news/2015/10/10/090708275/ limbah-beracun-intai-tarakan-kementeriansiap-siaga.

Tempo.co. (2016). Tanggung Jawab Sosial Perusahaan di Indonesia: Salah Paham? (Online). http://www.tempo.co/read/ kolom/2013/05/16/720/Tanggung-JawabSosial-Perusahaan-di-Indonesia.

Viva.co.id. (2014). Plus Minus Progam CSR di Indonesia. (Online). http://bisnis.news. viva.co.id/news/read/468051-plus-minusprogram-csr-di-indonesia. 